\title{
ANALISIS PENDAPATAN ASLI DAERAH DAN FAKTOR- FAKTOR YANG MEMPENGARUHINYA DALAM RANGKA OTONOMI DAERAH : PENDEKATAN ERROR CORRECTION MODEL
}

\author{
Oleh: \\ Dewi Oktavina \\ Sekretariat Daerah Provinsi Kalimantan Tengah \\ E-mail/No.Hp: dewi_okt@gmail.com/
}

\begin{abstract}
In most its management region autonomy therefore needful a policy in point of local government to increase ability in dig up its own finance potency one of its stemmed one of Propertied Original region (PAD), kerena is PAD'S Proportion to full scale region acceptance makes a abode to constitute financial independence degree indication a local government. To the effect that wants to be reached deep observational it is menganalisis factor that regards PAD. That factor cover: population local government expenditure and PDRB. Observed data in this research is datu runtut periodic time 1994 2008. Estimation model that utilized by Error Correction's Approaching Model.
\end{abstract}

Keywords: Commanding expenditure, Population, PDRB, Regions Original income

\begin{abstract}
Abstrak
Dalam terselenggaranya otonomi daerah maka diperlukan suatu kebijakan yang tepat dari pemerintah daerah untuk meningkatkan kemampuan dalam menggali potensi keuangannya sendiri salah satunya yang bersumber dari Pendapatan Asli daerah (PAD), kerena Proporsi PAD terhadap total penerimaan daerah tetap merupakan indikasi derajat kemandirian keuangan suatu pemerintah daerah. Tujuan yang ingin dicapai dalam penelitian ini adalah menganalisis faktor-faktor yang mempengaruhi PAD. Faktor-faktor tersebut meliputi : pengeluaran pemerintah daerah jumlah penduduk dan PDRB. Data yang diamati dalam penelitian ini adalah datu runtut waktu periode 1994-2008. Model estimasi yang digunakan Pendekatan Error Correction Model.
\end{abstract}

Kata Kunci: Pengeluaran pemerintah, Jumlah Penduduk, PDRB, PAD

\section{PENDAHULUAN}

Dengan berlakunya Undang-

undang Undang-undang nomor 32

Tahun 2004 tentang Pemerintahan

Daerah, maka setiap daerah diberikan

kewenangan untuk mengatur daerahnya sendiri. Dimana dalam Undang-undang 32 Tahun 2004 telah meletakkan perubahan yang fundamental dalam pelaksanaan kebijakan desentralisasi, dari yang semula didominasi oleh pusat 
kemudian bergeser dengan memberikan keleluasaan yang lebih besar kepada Pemerintah Daerah untuk menyelenggarakan otonomi daerah yang luas, nyata dan bertanggung jawab untuk memberdayakan diri terutama berkaitan dengan pengelolaan sumber dana yang dimilikinya untuk pembiayaan daerah.

Dalam terselenggaranya otonomi daerah maka diperlukan suatu kebijakan yang tepat dari pemerintah daerah untuk meningkatkan kemampuan dalam menggali potensi keuangannya sendiri salah satunya yang

Tabel 1. Derajat Otonomi Fiskal Kabupaten Barito Utara

\begin{tabular}{ccccc}
\hline No & Tahun & PAD & Total Penerimaan Daerah & $\begin{array}{c}\text { Derajat Otonomi } \\
\text { Fiskal } \\
(\%)\end{array}$ \\
\hline 1 & 2005 & $6,297,921,000.00$ & $209,398,471,000.00$ & 3.01 \\
\hline 2 & 2006 & $10,063,320,000.00$ & $319,500,000,000.00$ & 3.15 \\
\hline 3 & 2007 & $13,400,000,000.00$ & $424,800,000,000.00$ & 3.15 \\
\hline 4 & 2008 & $14,981,500,000.00$ & $451,276,388,000.00$ & 3.32
\end{tabular}

Sumber : Dirjen PKPD

Pada tabel 1. diatas pada tahun 2005-2008 di Kabupaten Barito Utara kontribusi PAD terhadap Total Penerimaan Daerah masih sangat kecil yakni rata-rata $3.16 \%$ setiap tahunnya. Dengan hasil tersebut berdasarkan kriteria yang dibuat oleh Badan Litbang Depdagri dan Fisifol UGM bahwa derajat otonomi fiskal Kabupaten yang berada diantara $0 \%$ sampai dengan $10 \%$ termasuk dalam kategori tingkat kemandirian daerah yang bersumber dari Pendapatan Asli daerah (PAD), karena PAD merupakan tolak ukur untuk melihat apakah suatu daerah bisa dikatakan mandiri atau tidak. Proporsi PAD terhadap total penerimaan daerah tetap merupakan indikasi derajat kemandirian keuangan suatu pemerintah daerah. Kemandirian keuangan suatu pemerintah daerah yang disebut juga Derajat Otonomi Fiskal (DOF), menurut Badan Litbang Departemen Dalam Negeri merupakan perbandingan antara PAD dengan total penerimaan daerah. 
masyarakat, yangmana pendanaanya pemerintah

pusat.

masih tergantung dari transfer

Tabel 2. Belanja Daerah dan Jumlah Penduduk di Kabupaten Barito Utara

\begin{tabular}{cccc}
\hline Tahun & Belanja Daerah (Rp) & Jumlah Penduduk (orang) & $\begin{array}{c}\text { Pertumbuhan Jumlah } \\
\text { Penduduk (\%) }\end{array}$ \\
\hline 2005 & $198,166,186,102.00$ & 111,334 & - \\
\hline 2006 & $330,967,770,621.00$ & 112,091 & 0.68 \\
\hline 2007 & $395,401,266,495.00$ & 116,360 & 3.81 \\
\hline 2008 & $504,800,747,071.00$ & 121,789 & 4.67 \\
\hline
\end{tabular}

Sumber : Kabupaten Barito Utara Dalam Angka

Melihat permasalahan ini, maka diperlukan suatu kebijakan yang tepat dari pemerintah daerah untuk meningkatkan kemampuan dalam menggali potensi keuangannya sendiri.

Salah satu sudut pandang kebijakan yang dapat dilakukan adalah melalui kebijakan pengeluaran pemerintah daerah yang dituangkan dalam Anggaran Pendapatan dan Belanja Daerah memerlukan perhatian terutama dalam hal pengalokasiaan anggaran, diupayakan dialokasikan pada sektor-sektor yang dapat merangsang terciptanya sumber-sumber pendapatan baru bagi daerah dan tentunya didukung oleh partisipasi dari masyarakat.

Berdasarkan uraian latar belakang, maka penelitian ini bertujuan menganalisis faktor-faktor yang mempengaruhi PAD. Faktor-faktor tersebut meliputi : pengeluaran pemerintah daerah, jumlah penduduk dan PDRB.
Otonomi daerah adalah untuk mengurangi ketergantungan pemerintah daerah terhadap pemerintah pusat terutama dalam masalah keuangan, sehingga daerah diharapkan mampu membiayai keuangannya secara mandiri. Salah satu yang menjadi perhatian pemerintah daerah adalah dalam pegelolaan penerimaan yang berasal dari daerah sendiri (Davey, 1988).

Fokus otonomi daerah terdiri dari 3 (tiga), yakni pertama : otonomi yang berfokus pada kewenangan administrasi pemerintah daerah, seperti pengurusan pegawai, pengeluaran dan pendapatan daerah; kedua : otonomi yang difokuskan kepada alokasi kekuasaan daerah yang disertai oleh kontrol pemerintah pusat dan partisipasi rakyat daerah; ketiga : penekanan pada pelaksanaan fungsi-fungsi pemerintah daerah yang dioperasikan lewat kewenangan daerah dalam mengelola 
urusan yang diberikan kepadanya (Sanit, 1991) .

salah satu faktor yang mempengaruhi dalam pelaksanaan otonomi daerah adalah faktor keuangan yang baik. Istilah keuangan disini mengandung arti bahwa setiap hak yang berhubungan dengan masalah uang, antara lain berupa sumber pendapatan, jumlah uang yang cukup, dan pengelolaan keuangan yang sesuai dengan tujuan dan peraturan yang berlaku (Riwo Kaho, 2001 ).

Purbayu Budi Santosa dan Retno Fuji Rahayu dalam penelitiannya Faktor-faktor yang diduga mempengaruhi presentasi perubahan PAD adalah Total pengeluaran pembangunan, penduduk dan PDRB sangat kuat. Ketiga variabel independen (Pengeluaran Pembangunan, Penduduk, PDRB), yang mempunyai pengaruh paling besar yaitu variabel penduduk.

Bachtiar (1992) dalam penelitiannya tentang otonomi dan implikasinya terhadap kemampuan keuangan daerah di Indonesia dari hasil regresi ditemukan bahwa PDRB adalah salah satu faktor yang mempengaruhi besarnya PAD dari suatu daerah. Semakin besar PDRB suatu daerah maka akan semakin tinggi PAD dari daerah yang bersangkutan. Jumlah penduduk adalah juga salah satu faktor yang mempengaruhi besarnya PAD dari suatu daerah. Namun pengaruh pertambahan jumlah penduduk tidak sebesar pengaruh dari penambahan PDRB.

Pengaruh struktur fiskal terhadap pertumbuhan ekonomi nasional dan lokal. Amerika Serikat yang sedang kesulitan anggaran berupaya meningkatkan pajak dan mengurangi pengeluaran pemerintah. Dari hasil penelitian menyimpulkan bahwa penerimaan pajak berpengaruh positif terhadap pertumbuhan ekonomi apabila penerimaan pajak digunakan untuk membangun infrastruktur, sebaliknya penerimaan akan berpengaruh negatif apabila digunakan untuk transfer paymen (Miller dan Russex, 1997).

Sumber pembiayaan pembangunan yang penting untuk diperhatikan adalah penerimaan daerah sendiri, karena sumber inilah yang merupakan wujud partisipasi langsung masyarakat suatu daerah dalam mendukung proses pembangunan. Penerimaan daerah sendiri yang merupakan wujud partisipasi masyarakat dalam bentuk pembayaran 
pajak dan retribusi daerah, harus mampu mendorong pertumbuhan ekonomi daerah, yang pada akhirnya akan menaikkan pendapatan daerah (Jaya, 1999).

Pendapatan Asli Daerah adalah penerimaan yang diperoleh daerah dari sumber-sumber dalam wilayahnya sendiri yang dipungut berdasarkan Peraturan Daerah sesuai dengan peraturan perundangan yang berlaku. Selanjutnya sumber-sumber PAD terdiri dari beberapa unsur yaitu; pajak daerah, retribusi daerah, Hasil perusahaan milik daerah dan hasil pengelolaan kekayaan daerah lainnya yang dipisahkannya, dan lain-lain pendapatan yang sah. Upaya meingkatkan PAD pada dasarnya ditempuh melalui upaya intensifikasi yang pelaksanaannya diantaranya melalui kegiatan sebagai berikut (Abdul Halim, 2004) Penyederhanaan prosedur administrasi yang dimaksudkan untuk memberi kemudahan bagi masyarakat membayar pajak dan retribusi daerah. Peningkatan dan Pengawasan yang efektif agar tidak terjadi penyimpangan dari prosedur pungutan dan pembayaran pajak dan retribusi daerah. Peningkatan Sumber Daya Manusia dengan mengerahkan sumber daya aparatur dalam pengelolaan pendapatan daerah.
Meningkatkan kegiatan penyuluhan kepada masyarakat, untuk menumbuhkan kesadaran masyarakat membayar retribusi dan pajak

Pajak adalah iuran rakyat kepada kas negara berdasarkan undang-undang yang dapat dipaksakan dengan tidak mendapat jasa timbal balik yang langsung dapat ditunjukkan dan yang digunakan untuk membayar pengeluaran umum( Mardiasmo, 1990).

Pengertian tentang retribusi, menurut bahwa retribusi (user fees) adalah semua biaya yang dikenakan pada semua individu untuk penggunaan layanan yang memberikan manfaat langsung kepada mereka. User fees bisa dianggap sebagai pajak konsumsi, dan bukan harga layanan yang diberikan. Dasar pendapat mereka adalah biaya pengguna berupaya menutup biaya operasi saja , umumnya dihitung berdasarkan penentuan biaya harga ratarata dan cenderung tidak diterapkan pada pendapatan untuk program dan fasilitas yang diberikan, tetapi pemerintah kota saat ini tengah mempertimbangkan biaya tak langsung dan alokasi pemindahan modal saat membuat penentuan harga. Selain itu sebagian besar sistem akunting pemerintah kota melaporkan 
pendapatan dari biaya pengguna (user fees) sebagai pengembalian langsung kepada program atau layanan yang diberikan ( lihat Mc Queen,1998).

$$
\text { Pengeluaran yang dilakukan }
$$
oleh Pemerintah yang dituangkan dalam Anggaran Pendapatan dan Belanja Daerah dapat dibedakan untuk pengeluaran konsumsi pemerintah (belanja rutin) serta untuk investasi pemerintah (belanja pembangunan/barang-barang modal). Pengeluaran pembangunan merupakan pengeluaran pemerintah untuk pelaksanaan proyek-proyek terdiri dari sektor-sektor pembangunan dengan tujuan untuk melakukan investasi. Belanja rutin meliputi seluruh pengeluaran yang dilakukan oleh pemerintah dalam rangka penyelenggaraan kegiatan administrasi pemerintahan mempunyai peranan dalam mendukung pencapaian sasaran pembangunan sekalipun pengeluaran tersebut tidak secara langsung berkaitan dengan pembentukan modal untuk tujuan peningkatan produksi, melainkan menunjang kegiatan pemerintahan serta peningkatan jangkauan dan mutu pelayanan (Abdul Halim, 2001).

Teori Peacock dan Wiseman adalah pemerintah ekonomi menyebabkan pemungutan pajak yang semakin meningkat walaupun tarif pajak tidak berubah dan meningkatnya penerimaan pajak menyebabkan pengeluaran pemerintah juga semakin meningkat. Oleh karena itu, dalam keadaan normal, meningkatnya GNP menyebabkan penerimaan pemerintah yang semakin besar, begitu juga dengan pengeluaran pemerintah menjadi semakin besar.

Wagner mengemukakan suatu teori mengenai perkembangan pengeluaran pemerintah yang semakin besar dalam pendapatan per kapita meningkat, secara relative pengeluaran pemerintahpun akan meningkat. Wagner menerangkan mengapa peran pemerintah menjadi semakin besar, yang terutama disebabkan karena pemerintah harus mengatur hubungan yang timbul dalam masyarakat, hukum, pendidikan, rekreasi, kebudayaan dan sebagainya. Wagner mendasarkan pandangannya dengan suatu teori yang disebut teori organis mengenai pemerintah (organic theory of the state) yang menganggap pemerintah sebagai individu yang bebas bertindak, terlepas dari anggota masyarakat lainnya. Teori mereka didasarkan pada suatu pandangan bahwa pemerintah 
senantiasa berusaha memperbesar pengeluaran, sedangkan masyarakat tidak suka membayar pajak yang semakin besar untuk membiayai pengeluaran pemerintah yang semakin besar tersebut.

Arthur Goldsmith menyatakan bahwa Belanja sektor publik dapat diklasifikasikan berdasar produktivitas. Membedakan antara pengeluaran pemerintah yang mempengaruhi produktivitas dan untuk konsumsi, maka diperlukan treatment ketidakseimbangan kebijakan fiskal dalam bentuk pengeluaran pemerintah yang memisahkan kedalam pengeluaran untuk konsumsi dan investasi. Pemerintah dapat meningkatkan pertumbuhan dengan mengubah komposisi pengeluaran kedalam kegiatan berbasis produktivitas, tanpa mengubah tingkat pengeluaran atau pajak penghasilan.

Adam Smith berpendapat bahwa dengan didukung bukti empiris bahwa pertumbuhan penduduk tinggi akan dapat menaikkan output melalui penambahan tingkat dan ekspansi pasar baik pasar dalam negeri maupun luar negeri. Penambahan penduduk tinggi yang diiringi dengan perubahan teknologi akan mendorong tabungan dan juga penggunaan skala ekonomi di dalam produksi. Penambahan penduduk merupakan satu hal yang dibutuhkan dan bukan suatu masalah, melainkan sebagai unsur penting yang dapat memacu pembangunan dan pertumbuhan ekonomi. Besarnya pendapatan dapat mempengaruhi penduduk. Jika jumlah penduduk meningkat maka pendapatan yang dapat ditarik juga meningkat.

PDRB merupakan alat ukur pertumbuhan ekonomi yang menggambarkan jumlah nilai produk barang dan jasa akhir yang dihasilkan oleh berbagai unit produksi dalam suatu wilayah atau region pada suatu jangka waktu tertentu. Dari sini dapat di lihat bahwa hubungan elastisitas antara pajak dearah yang diperoleh, dan pertumbuhan ekonomi yang dinilai dari pertumbuhan PDRB per kapita menggambarkan pertumbuhan yang otomatis dari potensi pajak. Dengan kata lain dalam konteks pajak daerah, semakin tinggi PDRB secara otomatis semakin tinggi pula pajak yang diterima daerah (Davey ,1988).

\section{METODE PENELITIAN}

Penelitian ini menggunakan data sekunder, yaitu data yang diperoleh dari 
Departemen Keuangan Direktorat Jendral PKPD dan Badan Pusat Statistik Kabupaten Barito Utara berupa Realisasi APBD, Jumlah Penduduk dan PDRB. Data yang dipergunakan dalam penelitian ini adalah data deret waktu (time series) tahunan mulai dari tahun 1994 sampai dengan 2008.

Pendapatan Asli Daerah (PAD) adalah pendapatan asli daerah sendiri yang terdiri dari hasil pajak, retribusi daerah, pendapatan dari dinas-dinas, BUMD dan lain-lain, dihitung dalam ribuan Rupiah per tahun.

Pengeluaran Pemerintah dalam hal ini Total Belanja Daerah (BD) yang digunakan adalah realisasi Belanja Daerah dinyatakan dalam satuan Rupiah. Jumlah penduduk (JP) yang digunakan adalah Jumlah penduduk dinyatakan dalam satuan orang. PDRB yang digunakan adalah PDRB atas dasar harga berlaku dinyatakan dala satuan Rupiah. Variabel Dummy adalah variabel yang digunakan untuk melihat pengaruh Pemekaran Kabupaten Barito Utara terhadp PAD.

Selanjutnya dari data yang ada akan dilihat bagaimana hubungan antar variabel dalam bentuk regresi dengan pendekatan error correction model (ECM), yangmana kemampuan yang dimiliki oleh ECM dalam meliput lebih banyak variabel untuk menganalisis fenomena ekonomi jangka pendek dan jangka panjang dan mengkaji konsisten tidaknya model empirik dengan teori ekonomika, serta dalam usaha mencari pemecahan terhadap persoalan variabel runtun waktu yang tidak stasioner (non stationarity) dan regresi lancung (spurious regression) atau korelasi lancung (spurious correlation) Dalam analisis ekonomika, ECM dapat pula dipakai untuk menjelaskan mengapa pelaku ekonomi menghadapi adanya ketidakseimbangan (disequilibrium) dalam konteks bahwa fenomena yang diinginkan (desired) oleh pelaku ekonomi belum tentu sama dengan kenyataan (actual) dan perlunya dilakukan penyesuaian (adjusment) sebagai akibat adanya perbedaan fenomena aktual yang dihadapi antar waktu.

Terhadap data yang gunakan dalam model penelitian, dilakukan pengujian stasioneritas data runtun waktu (time series). Konsep terkini yang banyak dipakai untuk menguji kestasioneran data runtun waktu adalah uji akar unit (unit root test) atau dikenal juga dengan uji Augmented Dickey Fuller (ADF). Uji Philips-Perron (PP) 
.Jika semua variabel lolos dari uji akar maka selanjutnya dilakukan uji kointegrasi untuk mengetahui kemungkinan terjadinya keseimbangan atau kestabilan jangka panjang diantara variabel- variabel yang diamati. Metode error correction model digunakan untuk melihat pengaruh jangka pendek dan jangka panjangnya.

Model ECM yang dikembangkan dari model dasar yang akan diestimasi pada penelitian ini dengan proses teknik reparameterisasi ini adalah sebagai berikut

$$
\begin{aligned}
\triangle P A D_{t}= & a_{0}+a_{1}\left(\Delta B D_{t-1}\right)+ \\
& a_{2}\left(\Delta J P_{t-1}\right)+ \\
& a_{3}\left(\Delta P D R B_{t-1}\right)+ \\
& a_{4} D U M M Y_{t-1}+E C T_{t-2}- \\
& \Delta P A D_{t-1}+U_{t}
\end{aligned}
$$

\section{PEMBAHASAN}

Sebelum pemekaran Luas wilayah secara keseluruhan Kabupaten Barito Utara adalah $32.000 \mathrm{Km}^{2} 8.300$ $\mathrm{Km}^{3}$ terdiri dari 11 Kecamatan, 1 Pembantu Bupati (Administratif Murung Raya. Pada Tahun 2002 terjadi pemekaran, Kabupaten Barito Utara luasnya menjadi $8.300 \mathrm{Km}^{3}$ dengan 6 Kecamatan, 3 desa dan 10 Kelurahan. Secara administratif Murung Raya menjadi Kabupaten tersendiri.
Tingkat pertumbuhan penduduk terbesar terjadi pada tahun 2007 dan 2008 yaitu sebesar 3.81 persen dan 467 . Sedangkan penurunan jumlah penduduk yakni pada tahun 2002, ini dampak Pemekaran Kabupaten Murung Raya dari Kabupaten Barito Utara

Peranan ekonomi sektoral PDRB Kabupaten Barito Utara kontribusi sektor terhadap PDRB menunjukkan sumbangan terbesar yaitu pada sektor pertambangan tanpa migas dan penggalian.

Pada tahun 1998 sampai 2005, pengeluaran rutin lebih besar dari pengeluaran pembangunan. Dengan adanya perbedaan yang besar antara pengeluaran rutin dan pembangunan ini menandakan bahwa pola pembangunan yang dijalankan masih bersifat konsumtif dan tidak dialokasikan pada sektor-sektor yang lebih produktif guna meningkatkan PAD nantinya.

Di Kabupaten Barito Utara kontribusi PAD terhadap Total Penerimaan Daerah masih sangat kecil yakni rata-rata $3.16 \%$ setiap tahunnya, yang mana penyelenggaraan pemerintahan dalam hal mendanai belanja/pengeluarannya masih sangat tergantung pada Dana Perimbangan dari Pemerintah Pusat. 
Pengujian akar- akar unit untuk semua variabel yang digunakan dalam analisis runtun waktu dilakukan untuk memenuhi kesahihan analisis Error Correction Model (ECM). Hal ini berarti bahwa data yang dipergunakan harus bersifat stasioner, atau dengan kata lain perilaku data yang stasioner memiliki varians yang tidak terlalu besar dan mempunyai kecenderungan Tabel 3 (a) Uji ADF untuk PAD pada I (1)

$-2.827141$

$-2.7989$

$-1.6307$

Tabel 3 (b) Uji PP untuk BD pada I (1) dengan Trend dan Intercept

\begin{tabular}{|c|c|c|c|}
\hline & & $1 \%$ Critical Value* & -4.8870 \\
\hline PP Test Statistik & -4.361272 & 5\% Critical Value & -3.8288 \\
\hline
\end{tabular}

Tabel 3 (c) Uji ADF untuk JP pada I (1)

\begin{tabular}{lccc}
\multirow{2}{*}{ ADF Test Statistik } & $1 \%$ Critical Value* & -2.7989 \\
& -3.781184 & $5 \%$ Critical Value & -1.9725 \\
& $10 \%$ Critical Value & -1.6307 \\
\hline
\end{tabular}

Tabel 3 (d) Uji ADF untuk PDRB pada I (1)

ADF Test Statistik
$1 \%$ Critical Value*

$5 \%$ Critical Value

$10 \%$ Critical Value
$-2.7989$

$-1.9725$

$-1.6307$
Untuk uji stasioneritas data dapat disimpulkan di sini, bahwa dari tiga variabel yang diamati, variabel PAD telah stasioner pada $\mathrm{I}=(1)$, variabel Pengeluaran Pemerintah (BD) stasioner pada $I=(1)$, variabel Jumlah Penduduk stasioner pada $I=(1)$ dan variabel PDRB stasioner pada $\mathrm{I}=(1)$.
Setelah dilakukan uji stasioneritas dan diyakini seluruh variabel yang diamati merupakan variabel yang sudah stasioner dan memiliki derajat yang sama, maka langkah selanjutnya adalah pengujian kointegrasi untuk melihat hubungan jangka panjang dari model tersebut. Jika Error Correction Term (ECT) stasioner 
pada level, maka memiliki kointegrasi

dalam jangka panjang.

Tabel 4 Uji ADF untuk ECT pada I (0)

\begin{tabular}{cccc}
\hline \multirow{3}{*}{ ADF Test Statistik } & \multirow{2}{*}{-3.650988} & Critical Value* & -2.7760 \\
& & $5 \%$ Critical Value & -1.9699 \\
& & $10 \%$ Critical Value & -1.6295 \\
\hline
\end{tabular}

$\mathrm{ECT}=$ Resid

Tabel 5. Hasil Estimasi Jangka Panjang dengan Error Correction Model ECM)

\begin{tabular}{crrrc}
\hline \hline Variabel & \multicolumn{1}{c}{ Coefficient } & \multicolumn{1}{c}{ Std. Error } & \multicolumn{1}{c}{ t-Statistic } & \multicolumn{1}{c}{ Prob. } \\
\hline \hline & $2.26 \mathrm{E}+09$ & $1.64 \mathrm{E}+09$ & 1.372968 & 0.2121 \\
Belanja Daerah & 0.049086 & 0.014349 & 3.420821 & 0.0111 \\
Jumlah Penduduk & 22025.20 & 119805.6 & 0.183841 & 0.8594 \\
PDRB & -0.008275 & 0.009814 & -0.843160 & 0.4270 \\
Dummy & $-4.90 \mathrm{E}+08$ & $2.40 \mathrm{E}+09$ & -0.204386 & 0.8439 \\
ECT & -1.487121 & 0.622322 & -2.389632 & 0.0482 \\
\hline \hline R-squared & 0.762015 & Prob(F-statistic) & & 0.037577 \\
\hline
\end{tabular}

Dari hasil estimasi di atas, dapat dijelaskan di sini bahwa model yang coba dibangun dengan dengan ECM, dikatakan berhasil. Ini bisa diketahui dari hasil koefisien variable ECT yang signifikan secara statistik pada dengan probabilti pada tingkat signifikan $10 \%$, yang menunjukan adanya kointegrasi antar variabel, maka penggunaan ECM dapat dilanjutkan. Dari hasil uji F dapat disampaikan di sini bahwa secara bersama - sama variabel independen (Belanja Daerah, Jumlah Penduduk dan Variabel Dummy) mempunyai pengaruh kepada variabel dependen. Dari uji $\mathrm{T}$ didapat hasil bahwa variabel Belanja Daerah secara individual berpengaruh secara signifikan terhadap variabel PAD, tetapi variable Jumlah Penduduk, PDRB dan Variabel Dummy berpengaruh tidak signifikan secara statistik. Nilai $\mathrm{R}^{2}$ dari regresi di atas menunjukkan angka $76,20 \%$ yang berarti bahwa 76,20\% dari variasi PAD dapat dijelaskan oleh variasi himpunan variabel bebasnya. Sedangkan sisanya (berkisar 23,28\%)peningkatan PAD dipengaruhi oleh variabel - variabel lainnya yang tidak dimasukkan dalam analisa ini.

Hasil analisis jangka panjang dalam model koreksi kesalahan menunjukan pengaruh variabel Belanja Daerah terhadap PAD menunjukan angka signifikan, ditunjukan dengan nilai t statistic > t tabel $(3.420821>$ 1.753) dengan tanda koefisien positif. Kondisi tersebut mengindikasikan, bahwa belanja daerah direalisasikan untuk pembangunan infrastruktur dan sarana prasarana serta peningkatan pelayanan pajak dan retribusi akan 
meningkatan Penerimaan Daerah dari sektor PAD di Kabupaten Barito Utara.

Variabel Jumlah penduduk dalam analisis jangka panjang menunjukan pengaruh yang tidak signifikan dengan nilai $\mathrm{t}$ statistik $<\mathrm{t}$ tabel $(0.183841<1.753)$, dengan koefisien positif. Yangmana ini mengambarkan laju pertumbuhan penduduk tidak diiringi upaya intensifikasi PAD dari Pemerintah Daerah kabupaten Barito Utara. Upaya intesifikasi PAD dapat dilakukan dengan cara antara lain yakni : Penyederhanaan prosedur administrasi yang dimaksudkan untuk memberi kemudahan bagi masyarakat membayar pajak/ retribusi daerah dan meningkatkan kegiatan penyuluhan kepada masyarakat untuk menumbuhkan kesadaran masyarakat membayar retribusi dan pajak.

Variabel PDRB dalam jangka panjang menunjukan pengaruh yang tidak signifikan terhadap PAD dengan $\mathrm{t}$ statistik $<\mathrm{t}$ table $(-0.843160<1.753)$ serta memiliki koefisien negatif, yang berarti setiap kenaikan PDRB akan diikuti pula dengan penurunan PAD. Hal ini dikarenakan sektor pemberi kontribusi terbesar adalah sektor
Pertambangan Non Migas dan Penggalian, yangmana Pemerintah Kabupaten Barito Utara lebih banyak menyetorkan hasil yang didapat ke Departemen Keuangan yang kemudian didistribusikan kembali dalam bentuk bantuan umum (block grant) melalui Provinsi. Faktor lain yang menyebabkan tidak adanya pengaruh PDRB terhadap PAD, yakni tenaga Kerja pada sektor pertambangan, sebagian besar bukan penduduk Kabupaten Barito Utara.

Variabel Dummy dalam analisis jangka panjang menunjukan pengaruh yang tidak signifikan dengan $t$ statistik $<\mathrm{t}$ table $(-0.204386<1.753)$, dengan koefisien negatif. Ini berarti tidak ada pengaruh yang signifikan terhadap peningkatan PAD dengan adanya Pemekaran Kabupaten Murung Raya dari Kabupaten Barito Utara.

Agar hasil empirik di atas dapat diterima secara ekonometrik, maka diperlukan syarat BLUE (Best, Linier, Unbias, Estimator) dari metode kuadrat terkecil (OLS). Pengujian yang dilakukan dalam model antara lain : Uji Autokorelasi, Linearitas dan normalitas. Hasil output dari uji tersebut secara ringkas dapat dilihat dari tabel dibawah ini. 
Tabel 6. (a) Uji Otokolerasi

\begin{tabular}{llll}
\hline F-statistic & 0.019935 & Probability & 0.980340 \\
Obs*R-squared & 0.102842 & Probability & 0.949879 \\
\hline
\end{tabular}

Nilai Probalilitas Obs*R-Squared sebesar $0.949879>5 \%$ yang menunjukan tidak Tabel 6 (b) Uji Linearitas ( ARCH Test)

\begin{tabular}{llll}
\hline F- & 0.013019 & Probability & 0.911416 \\
statistic & & & \\
\hline
\end{tabular}

adanya gejala otokolerasi (Ho : tidak ada kolerasi ditolak).

Nilai Probalilitas sebesar $0.911416>5 \%$ yang menunjukan bahwa data tersebut memenuhi asumsi linearitas.

Tabel 6.(c) Uji Normalitas

\begin{tabular}{llll}
\hline Jarque-bera & 0.672279 & Probability & 0.714523
\end{tabular}

Nilai Probalilitas sebesar 0.714523

$>5 \%$ yang menunjukan bahwa data tersebut memenuhi asumsi normalitas, artinya bahwa variabel pengganggu diasumsikan memiliki distribusi normal.

Hasil studi empirik yang direpresentasikan tabel 4.2.3 (a,b,c) menunjukkan bahwa model ECM dalam penelitian ini lolos dalam berbagai uji asumsi klasik, hal ini menunjukkan bahwa model empirik dianggap memiliki kemampuan yang baik dalam menjelaskan hubungan antar variabel dalam model.

Faktor-faktor yang diduga mempengaruhi PAD adalah Pengeluaran Pemerintah Daerah, jumlah penduduk dan PDRB, dari ketiga variabel independen ini yang memiliki pengaruh paling besar dalam jangka panjang yaitu variabel Pengeluaran Pemerintah. Jumlah penduduk dan Variabel Dummy menunjukan pengaruh yang tidak signifikan, sedangkan
PDRB menunjukan pengaruh yang tidak signifikan dan berpengaruh negatif terhadap PAD

\section{DAFTAR PUSTAKA}

Devas, Nick, Brian Binder, Anne Booth, Kenneth Davey and Roy Kelly. 1989. Keuangan Pemerintah Daerah di Indonesia, (terjemahan oleh Masri Maris). UI-Press, Jakarta.

BPS Kabupaten Barito Utara, Kabupaten Barito Utara Dalam Angka 1994 - 2009.

Goldsmith, Arthur. 2008. Rethinking The Relation Between Government Spending and Economic Growth : A Composition Approach to Fiscal Policy instruction for Principle Students. Journal of Economics Education, Spring.

Halim, Abdul, 2001. Bunga Rampai Manajemen Keuangan Daerah Edisi Revisi. Unit Penerbit dan Percetakan (UUP) AMP YPKN, Yogyakarta.

Insukindro, 1999,. Pemilihan Model Ekonomi Empirik Dengan 
Pendekatan Koreksi Kesalahan, Jurnal Ekonomi Dan Bisnis Indonesia, Vol.14:1- 8.

Mc Queen, Jim . 1998. Development of a Model User Fees-A Model on Policy Development in Creating and Maintaning User Fees for Municipatities; The Local Goverment Program Departemen of Political Science. Paper MPA Research. University of Western Otario.

Purbayu Budi Santosa dan Retno Fuji Rahayu. 2005. Analisis Pendapatan Asli Daerah (PAD) Dan FaktorFaktor Yang Mempengaruhinya Dalam Upaya Pelaksanaan Otonomi Daerah Di Kabupaten Kediri. Journal Dinamika Pembangunan, Vol.2 No. 1
Soemitro, Rahmat . 1990. Dasar-Dasar Hukum Pajak dan Pendapatan

Undang-Undang RI Nomor 32 tahun 2004 tentang Pemerintahan Daerah.

Undang-Undang RI Nomor 33 tahun 2004 tentang Perimbangan Keuangan antara Pemerintah Pusat dan Daerah.

Widarjono, Agus. 2005. Ekonometrika : Teori dan Aplikasinya Untuk Ekonomi dan Bisnis. EKONISIA Kampus Fakultas Ekonomi UII, Yogyakarta.

Yuliadi, Imamudin. 2009. Ekonometrika Terapan, Unit Penerbit Fakultas Ekonomi.

(UPFE-UMY). Yogyakarta. 